\title{
Public policy to reduce the learning gap between CONAFE and SEP students in the state of Michoacán, Mexico
}

\section{Política pública para reducir la brecha de aprendizaje entre estudiantes del CONAFE y de la SEP en el estado de Michoacán, México}

\author{
MOLINA-MARTÍNEZ, Rubén* \& VILLALPANDO-ZORRILLA, Juan Manuel \\ Universidad Michoacana de San Nicolás de Hidalgo, Institute of Economic and Business Research
}

ID $1^{\text {st }}$ Author: Rubén, Molina-Martínez, / ORC ID: 0000-0002-9840-6441, Research ID Thomson: K-7424-2018, CVU CONACYT ID: 147012

ID $1^{\text {st }}$ Coautor: Juan Manuel, Villalpando-Zorrilla / ORC ID: 0000-0003-2845-5202, CVU CONACYT ID: 745999

DOI: $10.35429 /$ JPE.2019.5.3.14.26

Received September 10, 2019; Accepted November 18, 2019

\begin{abstract}
This proposal is the result of a real qualitative and quantitative investigation of the conditions in which the educational system is for both organizations compared from 2000 to 2018 in Michoacán, The National Council for Educational Development (CONAFE) and the Ministry of Public Education (SEP). The validity of the hypothesis required the application of a multimodal structured survey in 2017 , and allowed to verify the learning gap between CONAFE and SEP students in Michoacán. The purpose of this chapter is to design an appropriate public policy on educational matters that allows solving the hypothesis: Reduce the learning gap between students of two public organisms that provide basic education in the state of Michoacán, CONAFE and the regular service of the SEP in general. The proposal is framed in the Logical Framework Methodology model, recommended for Mexico by the National Council for the Evaluation of Social Programs (CONEVAL). The proposal adds steps to the guiding model that allow clarifying how to design an educational public policy to be presented in the instances of programmatic decision; consider eleven stages and not just eight.
\end{abstract}

Educational Public Policy, Learning gap, CONAFE, regular service of SEP, Logical Framework Methodology

\section{Resumen}

En la presente investigación, se muestra un análisis jurídico nacional en correspondencia al derecho laboral de la participación de los trabajadores en las utilidades de las empresas en México, mostrando en el mismo estudio, su fundamentación jurídica y el procedimiento de cálculo conforme a lo establecido en la Constitución Política de los Estados Unidos Mexicanos, la Ley Federal del Trabajo y la Ley del Impuesto Sobre la Renta para el caso de las personas morales. Asimismo, con base en la estadística descriptiva se exhibe el comportamiento sobre la manifestación del cumplimiento en la presentación de la declaración anual del régimen fiscal analizado, así como la expresión de los montos distribuidos entre sus subordinados; con cifras emitidas por el Servicio de Administración Tributaria (SAT) en su padrón de contribuyentes y datos anonimizados por los ejercicios fiscales del 2010 al 2015. De igual forma, en atención a los datos disponibles de la Encuesta Nacional de Ingresos y Gastos en los Hogares (ENIGH) por los años 2012, 2014, 2015, 2016 y 2018, se ostenta una amplia brecha en la dispersión y bajos ingresos de la percepción económica presentada.

Reparto de utilidades, Derecho laboral, Personas morales

Citation: MOLINA-MARTÍNEZ, Rubén \& VILLALPANDO-ZORRILLA, Juan Manuel. Public policy to reduce the learning gap between CONAFE and SEP students in the state of Michoacán, Mexico. Journal-Public Economy. 2019. 3-5: 14-26

\footnotetext{
* Correspondence to Author (email: ruben.molinam@ gmail.com)

$\dagger$ Researcher contributing as first author
} 


\section{Introduction}

In this paper, the problem identified is resolved, which is the learning gap (BA), and it was possible to establish through a quantitative and qualitative research. The analysis allowed the BA to be determined as a dependent variable based on three independent variables, the Public Education Policy (PPE), the Socio-Economic Profile (PSE), and the School Potential (PE).

The Learning Gap can be defined as the difference in learning that exists between some students and others, considering the relationship of socioeconomic profile, school potential, the level of achievement of learning in reading and the institutional capacity of educational public policies to reach his objectives.

The Public Education Policy is defined as a set of interrelated decisions that are adopted by an actor or groups of political actors that involve the definition of goals and means for their achievement in the framework of solving a public educational problem, associated with decisions they adopt Governments and their representatives through their institutions.

The Socioeconomic Profile is defined as the socioeconomic status of the students, considering their context, their integration and school performance. And the School Power is the institutional capacity of the schools, which integrates the organizational aspects, resources, teaching profile and its evaluation.

Through a quantitative analysis of hard data, the result of international and national evaluations, the learning gap that our country maintains with respect to other countries and within the country was determined between two organizations that provide basic education, 1) CONAFE and 2) the SEP in its regular general services in public schools, focused on primary education in its field of oral and written language and communication, recognized as a "Spanish" subject. Without neglecting the other areas of knowledge: Mathematics and Science as a logical and theoretical consequence of the mastery of language, which can be observed in a concentrated way in Graphic 1. The study addressed the theories that support the study variables and their conceptualization for the entity. It was analyzed from two perspectives: 1) the humanistic critical theory adopted by UNESCO, and; 2) the economist functionalist theory, adopted by the OECD.
Both coincide in the search for better results and coordination in educational matters as a pillar of formation of the social individual necessary to face the challenges and problems of a globalized world.

Results concentrated in good and excellent level

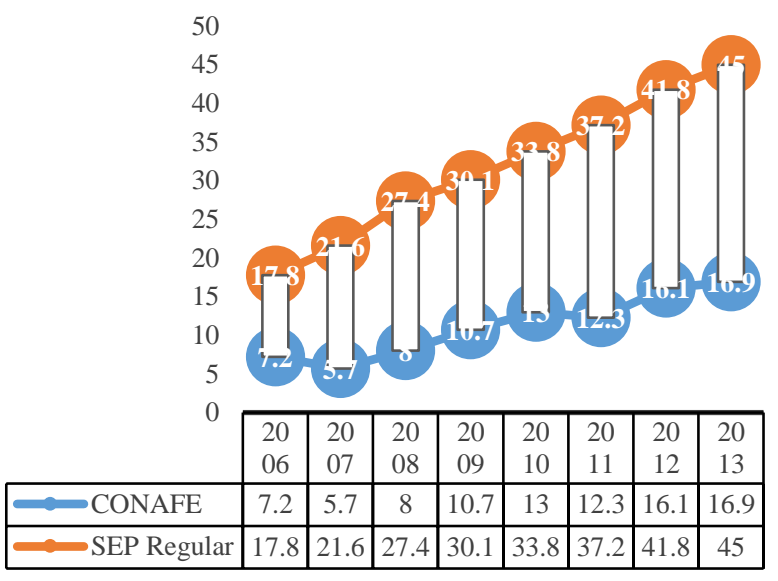

Graphic 1 Average results by modality in primary education, 2006-2013

Source: Own elaboration based on data from the Center for Social Studies and Public Opinion (CESOP, 2015)

The foregoing allowed the learning gap to be clearly established as a study problem, whose research hypothesis was put forward as follows: Implementing an educational public policy that allows improving the Socioeconomic Profile and School Potential of CONAFE students, it is possible close the learning gap that these maintain with respect to the students of the regular SEP, in primary education in Michoacán. As well as independent variables, 1) The Public Education Policy (PPE); 2) The Socioeconomic Profile (PSE), and; 3) The School Potential; in addition to the method and approaches proposed to address the problem analysis in context.

The analysis of the bibliography determined the most relevant aspects, elements and dimensions for the study variables and contextualized the necessary indicators for the design of the research survey, applied as a data collection instrument to the target population: teachers of the state of Michoacán, for the organizations involved in the provision of primary education to students of school age, both CONAFE and the regular SEP, and allowed to define the research variables from a socioeconomic, educational and normative perspective of educational public policies in our country. 
However, the educational gap, which is abstractly analyzed for primary education in the language (Spanish) has a smaller learning gap. Quantitative data show that for math and science, the gap is even greater; and it can be considered from the theory that these are a consequence of the construction of new knowledge under the domain of language.

The results obtained allowed to identify and analyze the highest peaks of behavior between the two organisms, and focus attention on the indicators that present the greatest differences. For which, a model of Cartesian graphical representation and linear mathematics was designed to quantify the study variables in a scheme. Combining the indicators of the variables from a non-probabilistic approach, through an analysis of weighted means of unit proportional behavior with data obtained from the applied survey, which are observed in Graphic 2.

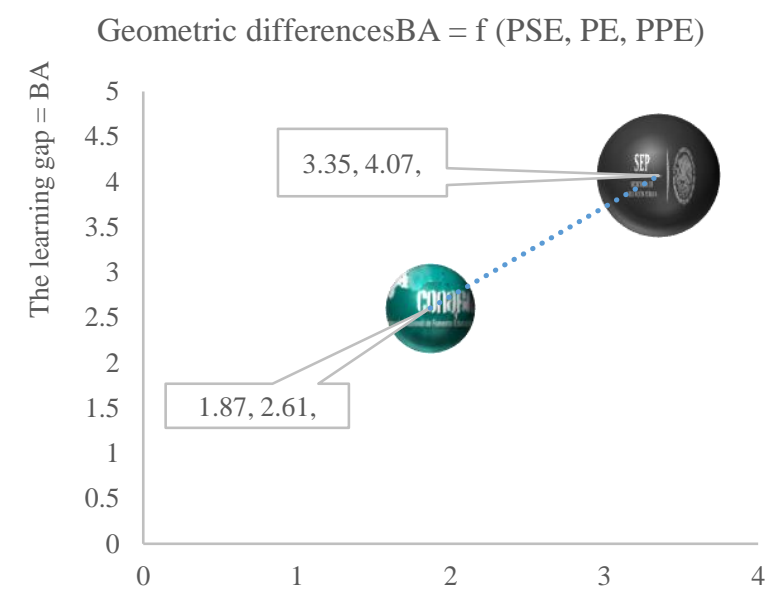

Graphic 2 Graphical representation of the components of the variables

Source: own elaboration with data from the applied research survey

It can be clearly seen that there is a significant difference in the value concentrates for each variable. For example, the Socioeconomic Profile (PSE) variable, CONAFE has a concentrated value of 1.87 points, while the SEP obtains a concentrated value of 3.35 points, which marks a gap between agencies for the same variable of 1.48 points, positive for the SEP. The same is true for the other variables, in the case of School Potential (PE) the difference is 1.46 points, also positive for the SEP; and in the case of the PPE the difference is again positive for the SEP with a difference of 6.71 points.
In general, the position of the sphere with respect to the learning gap that is quantified in the vertical axis (of the ordinates) shows that the farther up and up is the organism evaluated will be better. Therefore, the public policy to be designed will be one that allows improving CONAFE results and positions it as far to the right and up as necessary to reach the SEP body. The concentrated values of the SEP variables will be the new indicators to be achieved by CONAFE as objectives and goals in the design of Public Policy.

\section{Public Policy Proposal}

The arithmetic results obtained for the SEP (Graphic 2) will be the indicators that CONAFE will aim to achieve in Michoacán based on the hypothesis proposed to improve its results and indicators and reduce the learning gap that exists in its students regarding the Regular SEP in primary education in the state of Michoacán.

The public policy proposal in educational matters is made considering the elements and design model based on the Logical Framework Methodology (MML), recommended for the design, implementation and evaluation of public policies in our country by CONEVAL (ILPES, 2004), and must be aligned with the regulatory standards detailed below: The National Development Plan is aligned according to the Planning Law and the Political Constitution of the United Mexican States (art. 26 and 134), through the Federation Expenditure Budget (Results Based Budget), establishing that the Sectorial and Social Programs will have a Matrix of Results Indicators (MIR), a requirement of the long-term strategic planning of the Federal Public Administration and its federal entities for the fulfillment of the great national objectives, goals and government strategies; part of the New Public Management and Results Management strategy and the Performance Evaluation System. The MIR will be based on the Logical Framework Matrix.

The educational public policy proposal presented below is outlined in steps of a process, with aspects and elements that nourish the logical framework matrix (MML). It describes the analysis of those involved, the process of weighting specific weights of the groups involved, and their risks or threats in the possible intervention of public policy. 
The MIR, a consequence of the Logical Framework methodology, establishes the indicators of the budget program, for compliance. Subsequently, the costs of the program, the budget, its impact on the institutional macro budget and those responsible are addressed (considering the educational expenditure of the PEF 2016). Giving way to the proposal of educational public policy, which seeks to solve the research problem: The learning gap between the students of CONAFE and the regular SEP, in primary education, in the state of Michoacán.

\section{Analysis of involved}

The analysis of those involved is presented in the following Table of Expectations (1), in which the strength of 1 to 5 points is established, the negative valence for the resistance groups. The total result is the multiple of the valence by force. Positive results are expected to maintain compliance and effectiveness (efficiency and effectiveness). Leaders for Community Education or LEC teachers are considered involved for CONAFE. For the SEP, the most representative unions of the entity, the National Union of Education Workers (SNTE) and the National Coordinator of Education Workers (CNTE) are considered to be involved.

\begin{tabular}{|c|c|c|c|c|}
\hline Group & $\begin{array}{c}\text { Interest or expectation (positive, } \\
\text { if they benefit within the } \\
\text { program, and negative if it } \\
\text { hurts) }\end{array}$ & $\begin{array}{l}\text { Vale } \\
\text { ncia } \\
\text { (V) }\end{array}$ & $\begin{array}{l}\text { Str } \\
\text { en } \\
\text { gth } \\
(\mathrm{F})\end{array}$ & $\begin{array}{c}\text { Resul } \\
\text { ting } \\
(\mathrm{V} * \\
\mathrm{F})\end{array}$ \\
\hline $\begin{array}{l}\text { LEC's } \\
\text { currentl } \\
\text { y in } \\
\text { CONA } \\
\text { FE }\end{array}$ & $\begin{array}{l}\text { They are a focus of criticism for } \\
\text { the results and characteristics of } \\
\text { the system. However, they will } \\
\text { be great beneficiaries of } \\
\text { integrating the program. }\end{array}$ & $\begin{array}{l}\text { Posit } \\
\text { ive }\end{array}$ & 3 & +3 \\
\hline 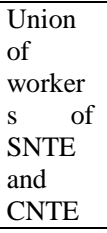 & $\begin{array}{l}\text { They are groups that can present } \\
\text { resistance, depending on the } \\
\text { possible hiring of teachers under } \\
\text { conditions of law and without } \\
\text { integrating them into any } \\
\text { teachers union. }\end{array}$ & $\begin{array}{l}\text { Nega } \\
\text { tive }\end{array}$ & 2 & -2 \\
\hline $\begin{array}{l}\text { Parties } \\
\text { and } \\
\text { politica } \\
1 \\
\text { groups }\end{array}$ & $\begin{array}{l}\text { In electoral times there is a high } \\
\text { burden of social and political } \\
\text { conflicts in communities far } \\
\text { from the entity. It can be a factor } \\
\text { that reduces the strength of the } \\
\text { program. }\end{array}$ & $\begin{array}{l}\text { Nega } \\
\text { tive }\end{array}$ & 1 & -1 \\
\hline $\begin{array}{l}\text { Village } \\
\text { rs in the } \\
\text { commu } \\
\text { nities }\end{array}$ & $\begin{array}{l}\text { Group directly and indirectly } \\
\text { benefited from the consolidation } \\
\text { of a better educational service, } \\
\text { so their support is expected. }\end{array}$ & $\begin{array}{l}\text { Posit } \\
\text { ive }\end{array}$ & 3 & +3 \\
\hline $\begin{array}{l}\text { CONA } \\
\text { FE } \\
\text { student } \\
\text { s }\end{array}$ & $\begin{array}{l}\text { They are the main beneficiaries. } \\
\text { The expectation is positive } \\
\text { considering the short-term } \\
\text { benefits in terms of resources. }\end{array}$ & $\begin{array}{l}\text { positi } \\
\text { ve }\end{array}$ & 3 & +3 \\
\hline
\end{tabular}

Table 1 Expectations table of the stakeholder analysis Source: own elaboration based on the MML (ILPES, 2004)
The behaviors of the groups or individuals involved can be differentiated by geography or other factors, such as crime and insecurity, or social groups that deprive in areas or regions of the entity. However, not all of these factors were possible to be included due to their complexity of study. In the end the arithmetic sum is positive of +6 points, which implies that there are more positive than negative aspects in the proposal.

\section{Problem Tree}

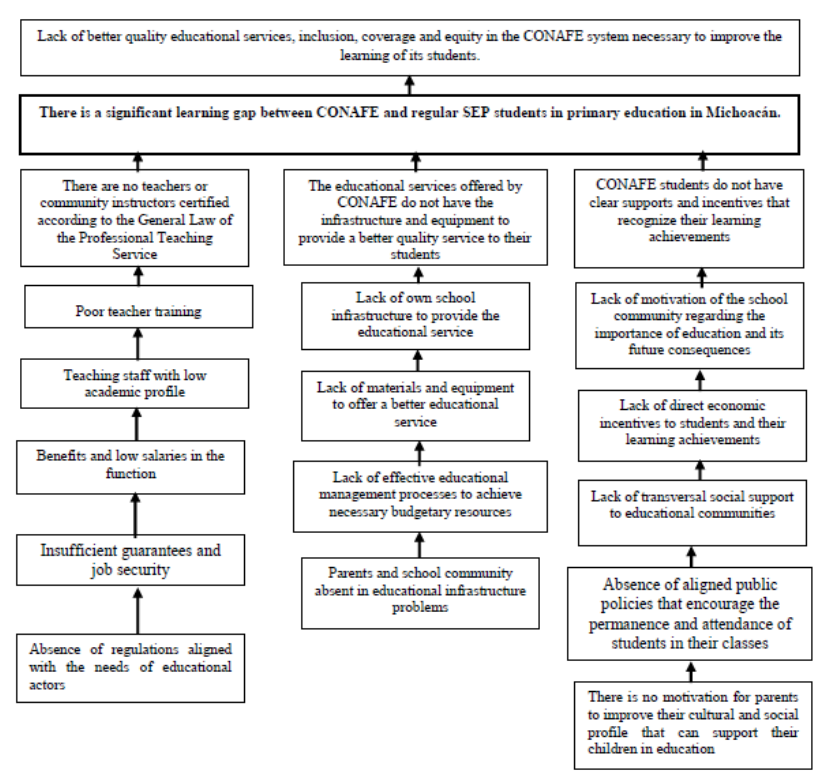

Figure 1 Problem Tree

Source: Own elaboration based on the MML (ILPES, 2004: CONAFE, 2016a, 2016b)

The problem tree, Figure 1, is the result of the diagnosis, foundation, conceptualization and identification of the research problem and its relational variables, which has been configured with the triangulation of hard data and the results of the field work (surveys and analysis of data) initially raised. 


\section{Objective Tree}

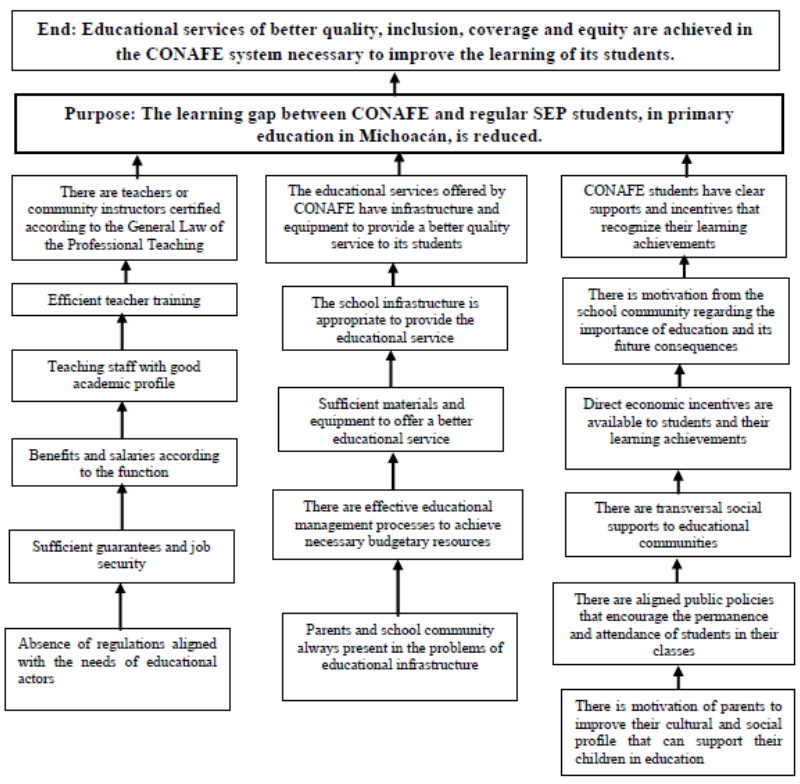

Figure 2 Objective Tree

Source: Own elaboration based on the MML (ILPES, 2004; CONAFE, 2016a, 2016b)

The objective tree presented in Figure 2 is the positive conversion of the negative situations detected in the problem tree.

\section{Alternative solutions}

In this phase it consists of analyzing in a strategic way the options that allow to reach the objectives. It is carried out, preferably, by levels, from below, (of the activities or level 4), to the components (level 3); and with it, achieve the ends and objectives (level 2 and 1). Looking for creative strategies of government actions, feasible and achievable, to solve, comprehensively, each problem encountered at each level of the process. It involves selecting the best options, tasks to be performed, within the sector or cross-sectional of other sectors. Among the solution alternatives, 4 stand out, taken into account to solve the identified problem. Components and their activities for the achievement of the proposed services:

A. Certify CONAFE teachers with a bachelor's level.

1. Free teacher update program.

2. Teacher hiring program based on the Law (LGSPD).

B. Equip with multipurpose classrooms for each group / for each LEC.

1. Donation of the land by the community.

2. Classroom construction.

\section{Classroom equipment.}

C. Grant scholarships for academic achievement to each student of CONAFE.

1. Guidelines and call for scholarships.

2. Participants or beneficiaries.

3. Delivery of scholarships to beneficiaries.

D. Modify contract regulations for LEC, according to the LGSPD.

1. Delivery of proposal to the executive instances.

2. Approval.

3. Implementation, control and monitoring.

4. Evaluation.

\section{Justification, coverage, target population}

The justification of the proposals is based on the public policies in force in our country and the alignment that, since 2011, concurs in relation to international human rights agreements, mandatory for Mexico. Considering in this, to the article Third constitutional, international agreements on educational matters, the National Development Plan 2013-2018, in relation to educational quality; and the National CONAFE Program, in its objective 1, to promote access to educational services in basic education.

In relation to coverage and target population, basic education is involved in the primary sub-level, for students enrolled in community education provided by CONAFE, at school age, existing, for 4,879 students and those incorporated into the dates prior to the implementation of the program, as well as the 485 community instructors (LECs) and their new incorporations.

The program considers the educational services provided by CONAFE in Michoacán, as the initial objective of the proposed educational public policy program, which will seek to reverse the results and close the learning gap detected in this research.

For this, the design considers a long-term evaluation period of (6 years), medium term ( 3 years), and short term (one year or school year). The goals and activities, as well as their followup, are set out in the design (paragraph 6.4). 


\section{Intervention Design}

The program will consist of addressing the 3 central aspects identified:

1. Teacher training and hiring of certified teaching staff.

2. Infrastructure and equipment of prototype multi-purpose classrooms in the communities where the community education service is offered.

3. Improvement of socioeconomic conditions of the school community, granting scholarships for academic and social achievements of students.

According to the variables: the learning gap, the socioeconomic profile and the school potential, and the educational public policy as a pivotal factor for the achievement of the objectives, it is reached, considering the intervention flow Figure (Figure 3).

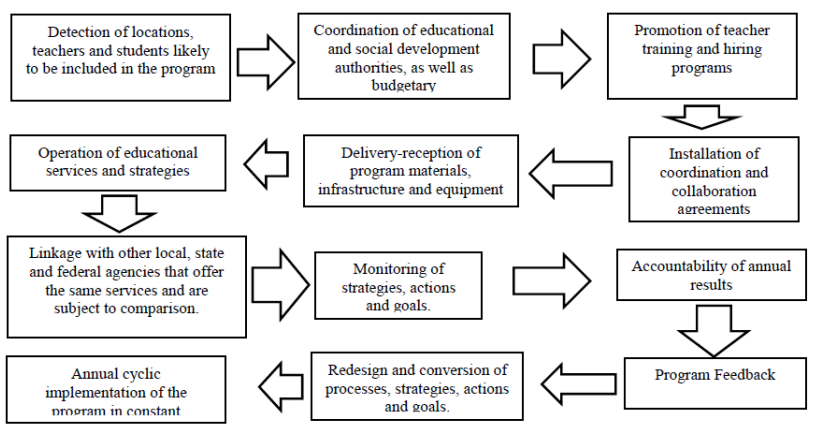

Figure 3 Intervention flow

Source: own elaboration based on the MML (ILPES, 2004: CONAFE, 2016)

\section{Logical Framework Matrix}

In the Logical Framework Matrix (table 2), the concentrated values of the variables for the SEP will be the indicators to be achieved by CONAFE. Therefore, it will seek to improve the aspects that influence the study variables for this organism, and are prioritized in the sense of the objective and goals proposed for a given time (long term $=6$ years; medium $=3$ years, already short term $=1$ year or school year). It is important to consider that the projected program implementation times do not necessarily coincide with the results evaluation times, and may be more extensive and / or subsequent to its implementation.

\begin{tabular}{|c|c|c|c|c|}
\hline & $\begin{array}{l}\text { Narrative } \\
\text { summary }\end{array}$ & Indicators & $\begin{array}{c}\text { Means of } \\
\text { verification }\end{array}$ & $\begin{array}{c}\text { Assumption } \\
\mathrm{s}\end{array}$ \\
\hline $\begin{array}{l}0 \\
0 \\
0 \\
0 \\
0 \\
0 \\
0 \\
0 \\
.0 \\
.00 \\
.00 \\
0\end{array}$ & $\begin{array}{l}\text { Close the } \\
\text { language } \\
\text { learning gap of } \\
\text { CONAFE } \\
\text { students } \\
\text { regarding the } \\
\text { regular SEP in } \\
\text { primary } \\
\text { education in } \\
\text { Michoacán }\end{array}$ & $\begin{array}{l}\text { Percentage of } \\
\text { CONAFE } \\
\text { students who } \\
\text { have managed } \\
\text { to close the } \\
\text { learning gap } \\
\text { regarding the } \\
\text { level of the } \\
\text { regular SEP. }\end{array}$ & $\begin{array}{l}\text { Results of } \\
\text { the applied } \\
\text { research } \\
\text { survey. And } \\
\text { data from } \\
\text { INEGI, SEP, } \\
\text { INEE and } \\
\text { PISA. }\end{array}$ & $\begin{array}{l}\text { The actors } \\
\text { improve } \\
\text { their } \\
\text { perception } \\
\text { of } \\
\text { community } \\
\text { education } \\
\text { and are } \\
\text { interested in } \\
\text { developing } \\
\text { their } \\
\text { learning. }\end{array}$ \\
\hline 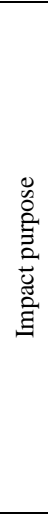 & $\begin{array}{l}\text { The language } \\
\text { learning gap } \\
\text { between } \\
\text { CONAFE and } \\
\text { the regular } \\
\text { primary SEP in } \\
\text { Michoacán has } \\
\text { closed. }\end{array}$ & $\begin{array}{l}\text { Percentage of } \\
\text { improvement } \\
\text { of the learning } \\
\text { gap. } \\
\text { Percentage of } \\
\text { improvement } \\
\text { of educational } \\
\text { public policy. } \\
\text { Percentage of } \\
\text { improvement } \\
\text { of the } \\
\text { socioeconomi } \\
\text { c profile. } \\
\text { Percentage } \\
\text { improvement } \\
\text { of school } \\
\text { potential. }\end{array}$ & $\begin{array}{l}\text { Results of } \\
\text { the applied } \\
\text { research } \\
\text { survey. } \\
\text { Focused } \\
\text { survey } \\
\text { application. } \\
\text { Statistical } \\
\text { data and } \\
\text { standards of } \\
\text { the SEP and } \\
\text { CONAFE. }\end{array}$ & $\begin{array}{l}\text { The } \\
\text { population } \\
\text { makes use of } \\
\text { the program } \\
\text { and its } \\
\text { services. } \\
\text { Teachers } \\
\text { meet and } \\
\text { commit to } \\
\text { the proposed } \\
\text { objectives. }\end{array}$ \\
\hline 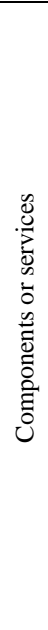 & $\begin{array}{l}\text { A. LEC with } \\
\text { higher } \\
\text { education } \\
\text { certificate in } \\
\text { CONAFE, } \\
\text { guaranteed. } \\
\text { B. } \\
\text { Multipurpose } \\
\text { room equipped } \\
\text { for each LEC, } \\
\text { working. } \\
\text { C. Scholarship } \\
\text { for academic- } \\
\text { social } \\
\text { achievement, } \\
\text { working. } \\
\text { D. Regulatory } \\
\text { modification } \\
\text { for teacher } \\
\text { contracts by the } \\
\text { LGSPD. }\end{array}$ & $\begin{array}{l}\text { Percentage of } \\
\text { LEC } \\
\text { instructors } \\
\text { trained at the } \\
\text { end of the } \\
\text { program. } \\
\text { Percentage of } \\
\text { multi-purpose } \\
\text { classrooms in } \\
\text { operation per } \\
\text { school year. } \\
\text { Number of } \\
\text { scholarships } \\
\text { awarded per } \\
\text { school year. } \\
\text { Number of } \\
\text { teachers hired } \\
\text { for CONAFE } \\
\text { under the } \\
\text { LGSPD. }\end{array}$ & $\begin{array}{l}\text { Registration } \\
\text { of the } \\
\text { objective } \\
\text { training } \\
\text { program. } \\
\text { Registration } \\
\text { of } \\
\text { classrooms } \\
\text { built and } \\
\text { functioning. } \\
\text { Registration } \\
\text { of the } \\
\text { scholarship } \\
\text { program to } \\
\text { target } \\
\text { population. } \\
\text { Budget } \\
\text { verification } \\
\text { in PPEF and } \\
\text { PEF's. }\end{array}$ & $\begin{array}{l}\text { What is } \\
\text { learned } \\
\text { applies. } \\
\text { Teachers } \\
\text { remain and } \\
\text { attend their } \\
\text { teaching } \\
\text { activities in } \\
\text { defined } \\
\text { places. } \\
\text { There is no } \\
\text { union } \\
\text { conflict with } \\
\text { the services } \\
\text { provided. }\end{array}$ \\
\hline 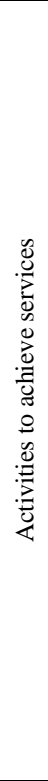 & $\begin{array}{l}\text { A.1. Free } \\
\text { teacher update. } \\
\text { A.2. Teacher } \\
\text { hiring based on } \\
\text { LGSPD. } \\
\text { B.1. Donation } \\
\text { of land. } \\
\text { B.2. Classroom } \\
\text { construction } \\
\text { B.3. Classroom } \\
\text { equipment. } \\
\text { C.1. Guidelines } \\
\text { and call. } \\
\text { C.2. } \\
\text { Participants. } \\
\text { C.3. } \\
\text { Scholarship } \\
\text { delivery. } \\
\text { D.1. Proposal } \\
\text { delivery. } \\
\text { D.2. Approval. } \\
\text { D.3 } \\
\text { Implementatio } \\
\text { n. } \\
\text { D.4 } \\
\text { Evaluation. }\end{array}$ & $\begin{array}{l}\text { Annual cost of } \\
\text { LEC training } \\
\text { Annual cost of } \\
\text { hiring via } \\
\text { LGSPD. } \\
\text { Construction } \\
\text { cost per } \\
\text { classroom. } \\
\text { Equipment } \\
\text { cost } \\
\text { Annual cost of } \\
\text { the } \\
\text { scholarship } \\
\text { program. } \\
\text { Cost of design, } \\
\text { planning, } \\
\text { management } \\
\text { and approval. } \\
\text { Cost of } \\
\text { implementatio } \\
\mathrm{n} \\
\text { Evaluation } \\
\text { cost }\end{array}$ & $\begin{array}{l}\text { Accounting } \\
\text { records of } \\
\text { the program. } \\
\text { Federation } \\
\text { Expenditure } \\
\text { Budget } \\
\text { Project } \\
\text { (PPEF). } \\
\text { PEF. } \\
\text { Reports of } \\
\text { the results of } \\
\text { the } \\
\text { organization } \\
\text { s involved } \\
\text { regarding } \\
\text { the program } \\
\text { implemente } \\
\text { d. }\end{array}$ & $\begin{array}{l}\text { Political will } \\
\text { of the actors } \\
\text { and decision } \\
\text { makers. } \\
\text { Financially } \\
\text { encourage } \\
\text { the students. } \\
\text { Communitie } \\
\text { s donate the } \\
\text { land. } \\
\text { Sufficient } \\
\text { budgetary } \\
\text { resources } \\
\text { are allocated } \\
\text { to fulfill the } \\
\text { program. }\end{array}$ \\
\hline
\end{tabular}

Table 1 Logical Framework Matrix

Source: own elaboration based on the MML (ILPES, 2004) 


\section{Matrix of results indicators (MIR)}

The matrix of results or monitoring indicators is aligned with the indicators established in the logical framework matrix (MML), developing the second column, so that it defines the indicators of each level, its method and calculation formula. The MIR matrix must be a single Table, but it is presented in 4 parts, for better visualization. Part 1, corresponds to the objective or purpose (upper level or level 1); then part 2, corresponds to purpose or impact (level 2); Subsequently, part 3 corresponds to the components (level 3); and part 4, corresponding to the activities (level 4). Each Table establishes the indicator, its objective, its definition, its method of calculation and its temporality of reference, as well as its unit of measurement. The rate is not considered because it is a newly created program. Part 1 , corresponding to the objective or purpose of the matrix.

\begin{tabular}{|c|c|c|c|c|c|}
\hline & $\begin{array}{l}\text { Indicato } \\
\text { rs }\end{array}$ & $\begin{array}{c}\text { Objectiv } \\
\text { e }\end{array}$ & Definition & $\begin{array}{l}\text { Calculation } \\
\text { method }\end{array}$ & $\begin{array}{c}\text { Refer } \\
\text { ence }\end{array}$ \\
\hline $\begin{array}{l}0 \\
0 \\
0 \\
0 \\
\vdots \\
0 \\
0 \\
0 \\
0 \\
0 \\
0 \\
0\end{array}$ & $\begin{array}{l}\text { Percenta } \\
\text { ge of } \\
\text { CONAF } \\
\text { E } \\
\text { students } \\
\text { who } \\
\text { have } \\
\text { managed } \\
\text { to close } \\
\text { the } \\
\text { learning } \\
\text { gap } \\
\text { regardin } \\
\text { g the } \\
\text { level of } \\
\text { the } \\
\text { regular } \\
\text { SEP. }\end{array}$ & $\begin{array}{l}\text { Contribut } \\
\text { e to } \\
\text { closing } \\
\text { the } \\
\text { learning } \\
\text { gap of all } \\
\text { CONAF } \\
\text { E elementar } \\
\text { y school } \\
\text { students, } \\
\text { regarding } \\
\text { students } \\
\text { of the } \\
\text { regular } \\
\text { SEP, in } \\
\text { language } \\
\text { and } \\
\text { communi } \\
\text { cation. }\end{array}$ & $\begin{array}{l}\text { It } \\
\text { measures } \\
\text { the } \\
\text { proportion } \\
\text { of students } \\
\text { who enter } \\
\text { the } \\
\text { program in } \\
\text { the } \\
\text { approval } \\
\text { cycle and } \\
\text { obtain } \\
\text { sufficient } \\
\text { or greater } \\
\text { results in } \\
\text { national or } \\
\text { internation } \\
\text { al tests in } \\
\text { the } \\
\text { subsequen } \\
\mathrm{t} \text { school } \\
\text { year. }\end{array}$ & $\begin{array}{l}\text { Students of } \\
\text { the program } \\
\text { that obtain } \\
\text { sufficient or } \\
\text { greater results } \\
\text { in national or } \\
\text { international } \\
\text { assessments } \\
\text { in the t-cycle } \\
\text { among the } \\
\text { total number } \\
\text { of students } \\
\text { enrolled in } \\
\text { the program } \\
\text { in year t-1) } \\
\text { multiplied by } \\
100 \text {. }\end{array}$ & $\begin{array}{l}\text { Period } \\
: \\
\text { Sexen } \\
\text { nial } \\
\text { Frequ } \\
\text { ency: } \\
\text { Annu } \\
\text { al } \\
\text { Unit } \\
\text { of } \\
\text { measu } \\
\text { remen } \\
\text { t: } \\
\text { Perce } \\
\text { ntage }\end{array}$ \\
\hline
\end{tabular}

Table 2 Matrix of Results Indicators or MIR (part 1. Objective)

Source: own elaboration based on the MML(ILPES, 2004, CONEVAL, 2018)

Part 2, corresponding to the level of purpose or impact of the matrix. It is presented below in Table 4.

\begin{tabular}{|c|c|c|c|c|c|}
\hline & $\begin{array}{l}\text { Indicat } \\
\text { ors }\end{array}$ & $\begin{array}{l}\text { objecti } \\
\text { ve }\end{array}$ & Definition & $\begin{array}{l}\text { Calculation } \\
\text { method }\end{array}$ & $\begin{array}{c}\text { Refer } \\
\text { ence }\end{array}$ \\
\hline & $\begin{array}{l}\text { Percent } \\
\text { age of } \\
\text { improve } \\
\text { ment of } \\
\text { the } \\
\text { learning } \\
\text { gap. }\end{array}$ & $\begin{array}{l}\text { Student } \\
\text { s who } \\
\text { particip } \\
\text { ate } \\
\text { present } \\
\text { improve } \\
\text { ments } \\
\text { in their } \\
\text { indicato } \\
\text { rs regardin } \\
\text { g the } \\
\text { learning } \\
\text { gap. }\end{array}$ & $\begin{array}{l}\text { It measures the } \\
\text { proportion of } \\
\text { students within } \\
\text { the program } \\
\text { who present an } \\
\text { improvement } \\
\text { in the } \\
\text { indicators of } \\
\text { the learning } \\
\text { gap in the final } \\
\text { annual } \\
\text { evaluation of } \\
\text { the school year } \\
\text { (applied } \\
\text { survey). }\end{array}$ & $\begin{array}{l}\text { (Students of } \\
\text { the program } \\
\text { that go from an } \\
\text { initial result } \\
\text { "r" to a better } \\
\text { one "r }+\mathrm{i} \text { ", } \\
\text { divided by the } \\
\text { total number } \\
\text { of participants } \\
\text { in cycle t) } \\
\text { multiplied by } \\
100 \text {. }\end{array}$ & $\begin{array}{l}\text { Period } \\
:\end{array}$ \\
\hline $\begin{array}{l}\overline{0} \\
\text { :्ञ } \\
\text {. } \\
\text { t) }\end{array}$ & $\begin{array}{l}\text { Percent } \\
\text { age of } \\
\text { improve } \\
\text { ment of } \\
\text { educati } \\
\text { onal } \\
\text { public } \\
\text { policy. }\end{array}$ & $\begin{array}{l}\text { The } \\
\text { students } \\
\text { who } \\
\text { particip } \\
\text { ate } \\
\text { present } \\
\text { improve } \\
\text { ments } \\
\text { in their } \\
\text { indicato } \\
\text { rs } \\
\text { regardin } \\
\text { g the } \\
\text { Public } \\
\text { Educati } \\
\text { on } \\
\text { Policy. }\end{array}$ & $\begin{array}{l}\text { It measures the } \\
\text { proportion of } \\
\text { students within } \\
\text { the program } \\
\text { who present an } \\
\text { improvement } \\
\text { in the } \\
\text { indicators of } \\
\text { educational } \\
\text { public policy in } \\
\text { the final annual } \\
\text { evaluation of } \\
\text { the school year } \\
\text { (applied } \\
\text { survey). }\end{array}$ & $\begin{array}{l}\text { (Students of } \\
\text { the program } \\
\text { that go from an } \\
\text { initial result } \\
\text { "r" to a better } \\
\text { one "r }+\mathrm{i} \text { ", } \\
\text { divided by the } \\
\text { total number } \\
\text { of participants } \\
\text { in cycle t) } \\
\text { multiplied by } \\
100 \text {. }\end{array}$ & $\begin{array}{l}\text { Sexen } \\
\text { nial }\end{array}$ \\
\hline 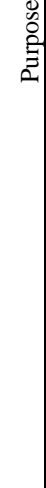 & $\begin{array}{l}\text { Percent } \\
\text { age of } \\
\text { improve } \\
\text { ment of } \\
\text { the } \\
\text { socio- } \\
\text { econom } \\
\text { ic } \\
\text { profile. }\end{array}$ & $\begin{array}{l}\text { Particip } \\
\text { ating } \\
\text { students } \\
\text { show } \\
\text { improve } \\
\text { ments } \\
\text { in their } \\
\text { indicato } \\
\text { rs } \\
\text { regardin } \\
\mathrm{g} \text { the } \\
\text { socio- } \\
\text { econom } \\
\text { ic } \\
\text { profile. }\end{array}$ & $\begin{array}{l}\text { It measures the } \\
\text { proportion of } \\
\text { students within } \\
\text { the program } \\
\text { who present an } \\
\text { improvement } \\
\text { in the } \\
\text { indicators of } \\
\text { the } \\
\text { socioeconomic } \\
\text { profile in the } \\
\text { final annual } \\
\text { evaluation of } \\
\text { the school year } \\
\text { (applied } \\
\text { survey). }\end{array}$ & $\begin{array}{l}\text { (Students of } \\
\text { the program } \\
\text { that go from an } \\
\text { initial result } \\
\text { "r" to a better } \\
\text { one "r }+\mathrm{i} \text { ", } \\
\text { divided by the } \\
\text { total number } \\
\text { of participants } \\
\text { in cycle t) } \\
\text { multiplied by } \\
100 \text {. }\end{array}$ & \\
\hline & $\begin{array}{l}\text { Percent } \\
\text { age } \\
\text { improve } \\
\text { ment of } \\
\text { school } \\
\text { potentia } \\
\text { 1. }\end{array}$ & $\begin{array}{l}\text { Student } \\
\mathrm{s} \quad \text { who } \\
\text { particip } \\
\text { ate } \\
\text { present } \\
\text { improve } \\
\text { ments } \\
\text { in their } \\
\text { indicato } \\
\text { rs } \\
\text { regardin } \\
\text { g school } \\
\text { potentia } \\
1\end{array}$ & $\begin{array}{l}\text { It measures the } \\
\text { proportion of } \\
\text { students within } \\
\text { the program } \\
\text { who present an } \\
\text { improvement } \\
\text { in the } \\
\text { indicators of } \\
\text { school } \\
\text { potential in the } \\
\text { final annual } \\
\text { evaluation of } \\
\text { the school year } \\
\text { (applied } \\
\text { survey). }\end{array}$ & $\begin{array}{l}\text { (Students of } \\
\text { the program } \\
\text { that go from an } \\
\text { initial result } \\
\text { "r" to a better } \\
\text { one "r }+\mathrm{i} \text { ", } \\
\text { divided by the } \\
\text { total number } \\
\text { of participants } \\
\text { in cycle t) } \\
\text { multiplied by } \\
100 \text {. }\end{array}$ & $\begin{array}{l}\text { Freque } \\
\text { ncy: }\end{array}$ \\
\hline
\end{tabular}

Table 3 Matrix of Results Indicators or MIR (part 2. Purpose).

Source: own elaboration based on the MML (ILPES, 2004, CONEVAL, 2018)

Part 3, corresponding to the matrix components is presented in Table 5 . 


\begin{tabular}{|c|c|c|c|c|c|}
\hline & $\begin{array}{l}\text { Indicator } \\
\quad \mathrm{s}\end{array}$ & Objective & Definition & $\begin{array}{l}\text { Calculatio } \\
\text { n method }\end{array}$ & Reference \\
\hline & $\begin{array}{l}\text { Percentag } \\
\mathrm{e} \text { of LEC } \\
\text { instructor } \\
\mathrm{s} \text { trained } \\
\text { at the end } \\
\text { of the } \\
\text { program. }\end{array}$ & $\begin{array}{l}\text { Training of } \\
\text { instructors } \\
\text { to measure } \\
\text { the } \\
\text { efficiency of } \\
\text { the program. }\end{array}$ & $\begin{array}{l}\text { Measure } \\
\text { the } \\
\text { percentage } \\
\text { of } \\
\text { instructors } \\
\text { enrolled in } \\
\text { the } \\
\text { program } \\
\text { who pass } \\
\text { the school } \\
\text { year } \\
\text { following } \\
\text { their } \\
\text { preparatio } \\
\text { n. }\end{array}$ & $\begin{array}{l}\text { (LEC } \\
\text { teachers of } \\
\text { the } \\
\text { program } \\
\text { that } \\
\text { approve } \\
\text { their cycle } \\
\text { or grade } \\
\text { level in } \\
\text { their } \\
\text { training at } \\
\text { time t, } \\
\text { divided by } \\
\text { the total } \\
\text { number of } \\
\text { teachers in } \\
\text { the } \\
\text { program in } \\
\text { year } t-1 \text { ) } \\
\text { multiplied } \\
\text { by } 100 .\end{array}$ & $\begin{array}{l}\text { Period: } \\
\text { Sexennial } \\
\text { Frequency: } \\
\text { Annual or } \\
\text { semi- } \\
\text { annual } \\
\text { Unit of } \\
\text { measureme } \\
\text { nt: } \\
\text { Percentage }\end{array}$ \\
\hline 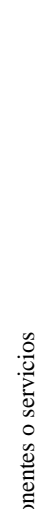 & $\begin{array}{l}\text { Percentag } \\
\mathrm{e} \quad \text { of } \\
\text { multi- } \\
\text { purpose } \\
\text { classroo } \\
\text { ms in } \\
\text { operation } \\
\text { per } \\
\text { school } \\
\text { year. }\end{array}$ & $\begin{array}{l}\text { Build } \\
\text { sufficient } \\
\text { school } \\
\text { infrastructur } \\
\text { e for } \\
\text { program } \\
\text { implementat } \\
\text { ion }\end{array}$ & $\begin{array}{l}\text { Measure } \\
\text { the } \\
\text { percentage } \\
\text { of multi- } \\
\text { purpose } \\
\text { classroom } \\
\text { s in } \\
\text { operation } \\
\text { per school } \\
\text { year with } \\
\text { respect to } \\
\text { the total } \\
\text { programm } \\
\text { ed }\end{array}$ & $\begin{array}{l}\text { Multipurp } \\
\text { ose } \\
\text { classrooms } \\
\text { in } \\
\text { operation } \\
\text { in the } \\
\text { school year } \\
t, \text { divided } \\
\text { by the total } \\
\text { number of } \\
\text { classrooms } \\
\text { projected at } \\
\text { the end of } \\
\text { the } \\
\text { program at } \\
\text { time t-1) } \\
\text { multiplied } \\
\text { by } 100 .\end{array}$ & $\begin{array}{l}\text { Period: } \\
\text { Biennial } \\
\text { Frequency: } \\
\text { Annual } \\
\text { Unit of } \\
\text { measureme } \\
\text { nt: } \\
\text { Percentage }\end{array}$ \\
\hline ڤ્छ & $\begin{array}{l}\text { Percentag } \\
\text { e of } \\
\text { scholarsh } \\
\text { ips } \\
\text { awarded } \\
\text { per } \\
\text { school } \\
\text { year. }\end{array}$ & $\begin{array}{l}\text { Contribute } \\
\text { to } \\
\text { improving } \\
\text { the learning } \\
\text { gap } \\
\text { according to } \\
\text { the socio- } \\
\text { economic } \\
\text { profile of the } \\
\text { participants }\end{array}$ & $\begin{array}{l}\text { It } \\
\text { measures } \\
\text { the } \\
\text { percentage } \\
\text { of school } \\
\text { scholarshi } \\
\text { ps of the } \\
\text { program } \\
\text { delivered } \\
\text { and } \\
\text { received at } \\
\text { time t, } \\
\text { with to } \\
\text { respect to } \\
\text { the total } \\
\text { programm } \\
\text { ed. }\end{array}$ & $\begin{array}{l}\text { Scholarshi } \\
\text { ps for the } \\
\text { program } \\
\text { awarded to } \\
\text { students at } \\
\text { time t, } \\
\text { divided by } \\
\text { the total } \\
\text { projected at } \\
\text { time t-1) } \\
\text { multiplied } \\
\text { by } 100 \text {. }\end{array}$ & $\begin{array}{l}\text { Period: } \\
\text { Sexennial } \\
\text { Frequency: } \\
\text { Annual or } \\
\text { semi- } \\
\text { annual } \\
\text { Unit of } \\
\text { measureme } \\
\text { nt: } \\
\text { Percentage }\end{array}$ \\
\hline & $\begin{array}{l}\text { Percentag } \\
\mathrm{e} \text { of } \\
\text { teachers } \\
\text { hired for } \\
\text { CONAFE } \\
\text { under the } \\
\text { LGSPD. }\end{array}$ & $\begin{array}{l}\text { Contribute } \\
\text { to the } \\
\text { program } \\
\text { compliance } \\
\text { with the law } \\
\text { (LGSPD) to } \\
\text { achieve the } \\
\text { suitability of } \\
\text { the } \\
\text { CONAFE } \\
\text { teaching } \\
\text { profile }\end{array}$ & $\begin{array}{l}\text { It } \\
\text { measures } \\
\text { the } \\
\text { percentage } \\
\text { of } \\
\text { CONAFE } \\
\text { teachers } \\
\text { who } \\
\text { comply } \\
\text { with the } \\
\text { hiring } \\
\text { rules } \\
\text { framed in } \\
\text { the } \\
\text { LGSPD in } \\
\text { force at the } \\
\text { start of the } \\
\text { program. }\end{array}$ & $\begin{array}{l}\text { (Teachers } \\
\text { hired } \\
\text { through the } \\
\text { law in force } \\
\text { at time t, } \\
\text { divided by } \\
\text { the total } \\
\text { number of } \\
\text { teachers } \\
\text { existing at } \\
\text { time t) } \\
\text { multiplied } \\
\text { by } 100 \text {. }\end{array}$ & $\begin{array}{l}\text { Period: } \\
\text { Sexennial } \\
\text { Frequency: } \\
\text { Annual or } \\
\text { semi- } \\
\text { annual } \\
\text { Unit of } \\
\text { measureme } \\
\text { nt: } \\
\text { Percentage }\end{array}$ \\
\hline
\end{tabular}

Table 4 Matrix of Results Indicators or MIR (part 3. Components)

Source: own elaboration based on the MML (ILPES, 2004, CONEVAL, 2018)

Part 4, corresponding to the activities for the achievement of the matrix (Table 6).

\begin{tabular}{|c|c|c|c|c|c|}
\hline & Indicators & objective & Definition & $\begin{array}{l}\text { Calculation } \\
\text { method }\end{array}$ & $\begin{array}{l}\text { Referenc } \\
\text { e }\end{array}$ \\
\hline \multirow{8}{*}{ 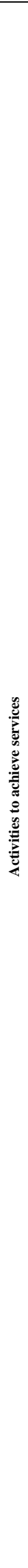 } & $\begin{array}{l}\text { Annual cost } \\
\text { of LEC } \\
\text { training. }\end{array}$ & $\begin{array}{l}\text { Establish } \\
\text { the annual } \\
\text { amount } \\
\text { allocated to } \\
\text { the training } \\
\text { of the LECs }\end{array}$ & $\begin{array}{l}\text { It measures } \\
\text { the annual } \\
\text { cost of teacher } \\
\text { training aimed } \\
\text { at improving } \\
\text { the academic } \\
\text { profile of the } \\
\text { LEC at time t, } \\
\text { until they } \\
\text { achieve their } \\
\text { professionaliz } \\
\text { ation (degree). }\end{array}$ & $\begin{array}{l}\text { Sum of } \\
\text { costs } \\
\text { allocated to } \\
\text { teacher } \\
\text { training of } \\
\text { LECs in } \\
\text { year t. }\end{array}$ & $\begin{array}{l}\text { Periodo: } \\
\text { Sexenal } \\
\text { Frecuenci } \\
\text { a: } \\
\text { Anual } \\
\text { Unidad de } \\
\text { medida: } \\
\text { Pesos }\end{array}$ \\
\hline & $\begin{array}{l}\text { Annual cost } \\
\text { of hiring } \\
\text { teachers via } \\
\text { LGSPD. }\end{array}$ & $\begin{array}{l}\text { Determine } \\
\text { the annual } \\
\text { amount of } \\
\text { teacher } \\
\text { hiring via } \\
\text { the LGSPD } \\
\text { lay }\end{array}$ & $\begin{array}{l}\text { It measures } \\
\text { the annual } \\
\text { cost of hiring } \\
\text { teachers of the } \\
\text { program } \\
\text { through the } \\
\text { LGSPD lay in } \\
\text { year } t\end{array}$ & 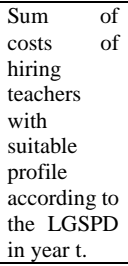 & $\begin{array}{l}\text { Periodo: } \\
\text { Sexenal } \\
\text { Frecuenci } \\
\text { a: } \\
\text { Anual } \\
\text { Unidad de } \\
\text { medida: } \\
\text { Pesos }\end{array}$ \\
\hline & $\begin{array}{l}\text { Average } \\
\text { cost of } \\
\text { constructio } \\
n \text { per } \\
\text { classroom. }\end{array}$ & $\begin{array}{l}\text { Establish } \\
\text { the average } \\
\text { unit cost of } \\
\text { construction } \\
\text { of the } \\
\text { multipurpos } \\
\text { e } \\
\text { classrooms } \\
\text { of the } \\
\text { program }\end{array}$ & $\begin{array}{l}\text { Measure the } \\
\text { average } \\
\text { construction } \\
\text { cost of each } \\
\text { multi-purpose } \\
\text { classroom at } \\
\text { time t at } \\
\text { current prices. }\end{array}$ & $\begin{array}{l}\text { Sum of } \\
\text { construction } \\
\text { costs of all } \\
\text { multi- } \\
\text { purpose } \\
\text { classrooms } \\
\text { at time t, } \\
\text { divided by } \\
\text { the number } \\
\text { of } \\
\text { classrooms. }\end{array}$ & $\begin{array}{l}\text { Period: } \\
\text { Sexennial } \\
\text { Frequency } \\
: \\
\text { Annual } \\
\text { Unit of } \\
\text { measurem } \\
\text { ent: } \\
\text { Pesos }\end{array}$ \\
\hline & $\begin{array}{l}\text { Average } \\
\text { cost of } \\
\text { equipment. }\end{array}$ & $\begin{array}{l}\text { Establish } \\
\text { the average } \\
\text { unit cost of } \\
\text { equipment } \\
\text { for the } \\
\text { multipurpos } \\
\mathrm{e} \\
\text { classrooms } \\
\text { of the } \\
\text { program }\end{array}$ & $\begin{array}{l}\text { Measure the } \\
\text { average } \\
\text { equipment } \\
\text { cost of each } \\
\text { multi-purpose } \\
\text { classroom at } \\
\text { time t at } \\
\text { current prices. }\end{array}$ & $\begin{array}{l}\text { Sum of } \\
\text { equipment } \\
\text { costs of all } \\
\text { multipurpos } \\
\mathrm{e} \\
\text { classrooms } \\
\text { at time t, } \\
\text { divided by } \\
\text { the number } \\
\text { of } \\
\text { classrooms. }\end{array}$ & $\begin{array}{l}\text { Period: } \\
\text { Sexennial } \\
\text { Frequency } \\
: \\
\text { Annual } \\
\text { Unit of } \\
\text { measurem } \\
\text { ent: } \\
\text { Pesos } \\
\end{array}$ \\
\hline & $\begin{array}{l}\text { Annual cost } \\
\text { of the } \\
\text { scholarship } \\
\text { program. }\end{array}$ & $\begin{array}{l}\text { Establish } \\
\text { the annual } \\
\text { amount of } \\
\text { the cost of } \\
\text { school } \\
\text { scholarships }\end{array}$ & $\begin{array}{l}\text { It measures } \\
\text { the annual } \\
\text { amount of the } \\
\text { cost of } \\
\text { scholarships } \\
\text { for students } \\
\text { participating } \\
\text { in the } \\
\text { program. }\end{array}$ & $\begin{array}{l}\text { Sum of } \\
\text { costs of all } \\
\text { scholarships } \\
\text { for students } \\
\text { of the } \\
\text { program in } \\
\text { year t. }\end{array}$ & $\begin{array}{l}\text { Period: } \\
\text { Sexennial } \\
\text { Frequency } \\
: \\
\text { Annual } \\
\text { Unit of } \\
\text { measurem } \\
\text { ent: } \\
\text { Pesos } \\
\end{array}$ \\
\hline & $\begin{array}{l}\text { Cost of } \\
\text { design, } \\
\text { planning, } \\
\text { manageme } \\
\text { nt and } \\
\text { approval. }\end{array}$ & $\begin{array}{l}\text { Establish } \\
\text { the annual } \\
\text { amount of } \\
\text { the cost of } \\
\text { design, } \\
\text { planning, } \\
\text { managemen } \\
t \text { and } \\
\text { approval of } \\
\text { the } \\
\text { program. }\end{array}$ & $\begin{array}{l}\text { It measures } \\
\text { the annual } \\
\text { amount of the } \\
\text { cost of design, } \\
\text { planning, } \\
\text { resource } \\
\text { management } \\
\text { and program } \\
\text { approval. }\end{array}$ & $\begin{array}{l}\text { Sum of } \\
\text { design, } \\
\text { planning, } \\
\text { managemen } \\
t \text { and } \\
\text { approval } \\
\text { costs of the } \\
\text { program at } \\
\text { time t. }\end{array}$ & $\begin{array}{l}\text { Period: } \\
\text { Sexennial } \\
\text { Frequency } \\
: \\
\text { Annual } \\
\text { Unit of } \\
\text { measurem } \\
\text { ent: } \\
\text { Pesos }\end{array}$ \\
\hline & $\begin{array}{l}\text { Cost of } \\
\text { implementa } \\
\text { tion }\end{array}$ & $\begin{array}{l}\text { Establish } \\
\text { the annual } \\
\text { amount of } \\
\text { program } \\
\text { implementa } \\
\text { tion, } \\
\text { monitoring } \\
\text { and control }\end{array}$ & $\begin{array}{l}\text { It measures } \\
\text { the annual } \\
\text { cost for } \\
\text { implementati } \\
\text { on, } \\
\text { monitoring } \\
\text { and control of } \\
\text { the program. } \\
\text { It includes } \\
\text { material, } \\
\text { human and } \\
\text { financial } \\
\text { resources. }\end{array}$ & $\begin{array}{l}\text { Sum of } \\
\text { costs of } \\
\text { implementa } \\
\text { tion, } \\
\text { monitoring } \\
\text { and control } \\
\text { of the } \\
\text { program in } \\
\text { time t. }\end{array}$ & $\begin{array}{l}\text { Period: } \\
\text { Sexennial } \\
\text { Frequency } \\
: \\
\text { Annual } \\
\text { Unit of } \\
\text { measurem } \\
\text { ent: } \\
\text { Pesos }\end{array}$ \\
\hline & $\begin{array}{l}\text { Evaluation } \\
\text { costs }\end{array}$ & $\begin{array}{l}\text { Establish } \\
\text { the annual } \\
\text { amount of } \\
\text { the internal } \\
\text { and external } \\
\text { evaluation } \\
\text { of the } \\
\text { program, as } \\
\text { well as its } \\
\text { accountabili } \\
\text { ty. }\end{array}$ & $\begin{array}{l}\text { It measures } \\
\text { the annual } \\
\text { cost for the } \\
\text { evaluation } \\
\text { and } \\
\text { accountability } \\
\text { of the } \\
\text { program. It } \\
\text { includes } \\
\text { internal and } \\
\text { external } \\
\text { evaluation. }\end{array}$ & $\begin{array}{l}\text { Sum of } \\
\text { evaluation } \\
\text { and } \\
\text { accountabili } \\
\text { ty costs of } \\
\text { the program } \\
\text { at time t. }\end{array}$ & $\begin{array}{l}\text { Period: } \\
\text { Sexennial } \\
\text { Frequency } \\
: \\
\text { Annual } \\
\text { Unit of } \\
\text { measurem } \\
\text { ent: } \\
\text { Pesos }\end{array}$ \\
\hline
\end{tabular}

Table 5 Matrix of Results Indicators or MIR (part 4. Activities)

Source: own elaboration based on the MML (ILPES, 2004, CONEVAL, 2018) 
In the activity phase it is possible to calculate progress percentages in relation to costs. However, because it is a new program, it is more feasible to calculate the amounts by activity and in the matrix of indicators of the second year to be able to calculate percentages or rates, and also to be able to establish compliance means.

\section{Estimation of operating costs}

The cost estimates, as well as the budget and impact, which are developed below are based on the 2016 Federation Expenditure Budget, and the unit costs are obtained from the means established for the costs of each service of the same year. The amounts are approximate but can be considered for the initial calculation of the final budget runs according to the applicable budget law (DOF, 2015).

\begin{tabular}{|c|c|c|c|}
\hline Service & Description & $\begin{array}{l}\text { Annual unit } \\
\text { cost approx. }\end{array}$ & $\begin{array}{l}\text { Total annual } \\
\text { cost approx. }\end{array}$ \\
\hline $\begin{array}{l}\text { Recruitment } \\
\text { of certified } \\
\text { teachers }\end{array}$ & $\begin{array}{l}\text { It requires the } \\
\text { hiring of } 485 \\
\text { teachers with } \\
\text { teaching } \\
\text { certificate } \\
\text { (degree). }\end{array}$ & $\$ 84,000.00$ & $\$ 40,740,000.00$ \\
\hline $\begin{array}{l}\text { LEC } \\
\text { Instructor } \\
\text { Training }\end{array}$ & $\begin{array}{l}\text { Training of at } \\
\text { least } 61 \% \text { of } \\
\text { the } 485 \text { LECs } \\
\text { with a } \\
\text { baccalaureate } \\
\text { certificate, to } \\
\text { achieve their } \\
\text { higher } \\
\text { education } \\
\text { certification } \\
\text { ( } 396 \\
\text { individuals). }\end{array}$ & $\$ 15,000.00$ & $\$ 5,940,000.00$ \\
\hline $\begin{array}{l}\text { Prototype } \\
\text { classrooms }\end{array}$ & $\begin{array}{l}485 \text { prototype } \\
\text { classrooms } \\
\text { per } \\
\text { community / } \\
\text { educational } \\
\text { service } \\
\text { teacher. }\end{array}$ & $\$ 1,000,000.00$ & $\$ 485,000,000.00$ \\
\hline $\begin{array}{l}\text { Prototype } \\
\text { classroom } \\
\text { equipment }\end{array}$ & $\begin{array}{l}\text { Classroom } \\
\text { equipment } \\
\text { with furniture } \\
\text { and } \\
\text { equipment. }\end{array}$ & $\$ 100,000.00$ & $\$ 48,500,000.00$ \\
\hline $\begin{array}{l}\text { Student } \\
\text { Scholarships } \\
/ \quad \text { School } \\
\text { Achievement }\end{array}$ & $\begin{array}{l}\text { Consider } \\
4,879 \\
\text { students, at } \\
\text { an average } \\
\text { incentive: \$ } \\
220 \\
\text { bimonthly. }\end{array}$ & $\$ 1,100.00$ & $\$ 5,366,900.00$ \\
\hline $\begin{array}{l}\text { Process } \\
\text { management, } \\
\text { planning, } \\
\text { design and } \\
\text { monitoring. }\end{array}$ & $\begin{array}{l}\text { Consider a } \\
\text { process } \\
\text { management } \\
\text { team of } 6 \\
\text { people. }\end{array}$ & $\$ 150,000.00$ & $\$ 900,000.00$ \\
\hline Total & & $\$ 1,350,100.00$ & $\$ 585,446,900.00$ \\
\hline
\end{tabular}

Table 6 Estimación de costos del proyecto o programa de intervención

Source: Own elaboration based on the MML (ILPES, 2004: CONAFE, 2016)
It is possible to dispense or reduce some costs depending on suppliers and priority activities that can be determined when designing the tentative budget. It is proposed to consider $6 \%$ of the total amount for operating expenses, not included in the costs of processes, planning, design and monitoring of Table 1.

\section{Budget and budgetary impact}

\section{Budget}

The budget considered for the operation of the program is additional to that allocated by the Chamber of Deputies and the PEF 2016, for the agency (CONAFE). For what is required of the management in the legislature and in the design of the budget by the SHCP (DOF, 2015). The efforts and managers are expected to carry out the proceedings in the units involved and their extension is achieved, which is currently around 5 billion pesos annually in the chapters of direct and indirect current expenditure.

\section{Budget impact}

The budgetary impact represents an approximate of 11 to $12 \%$ additional to the budget approved in the $2016 \mathrm{PEF}$ of 4.9 billion pesos per year (considering that the 2017 public account has not yet been approved or completed at the date of publication of the text).

\section{Responsible}

The implementation, monitoring, control, evaluation and accountability will be in charge of the executive authorities of the CONAFE services agency. The external evaluation will be carried out by the authorities destined for this purpose, CONEVAL, the INEE or some agency contracted for it. It is possible to include international organizations such as the OECD and UNESCO. The publication of results will be in charge of the agency, in compliance with the applicable regulatory and regulatory provisions.

\section{Educational public policy proposal}

With the intention that the proposal be clearly identified from its nomenclature, a title is proposed according to the problem that is intended to be solved, so it is assigned:

\section{"NO LEARNING GAP"}


The program "Without learning gap" is a strategy of inclusion, equity and social justice in educational matters, of a state nature, which in its first stage will have as its objective focused the school communities of CONAFE of primary education in Michoacán. It seeks to guarantee access to quality education in terms of the third constitutional article, allowing to improve the results and achieve educational goals, leveling learning in relation to regular SEP students in the short, medium and long term, generating a standard Starting from student learning that allows joint progress towards the objectives and goals proposed by national and international organizations in the field of evaluation.

For the achievement of its objectives, it considers the coordination between the dependencies of the public administration and federal, state and local agencies that directly affect CONAFE and the SEP, federal and decentralized in the state of Michoacán, as well as organisms, dependencies and transversal programs of possible contribution in the solution of the multifactor problem implicit in the task. Similarly, establish coordination with the entities and bodies for evaluation, transparency and accountability.

The institution responsible for the program will be a decentralized body of the SEP, coordinated with the institutions and agencies of the public administration through the Education Sector Program and the National Development Plan.

\section{Linked institutions}

Intersectoral commission of plans and programs derived from the PND. Instance of collaboration and strengthening of the lines of action between the sectors and programs Educational, Social Development and Health, and levels of government.

The Secretary of Public Education, SEP. In its federal and state decentralized scope in Michoacán.

The National Council for Educational Development, CONAFE, in its federal and delegation in the state of Michoacán. The National Institute of Educational Evaluation, in its national scope of contribution for the establishment of educational indicators and guidelines.
- The General Coordination of the Professional Teaching Service, CGSPD, in its national field of contribution to the professional development of teachers.

- $\quad$ The Secretary of Social Development, SEDESOL, in its transversal scope and contribution to educational goals.

- The Ministry of Social and Human Development in the State of Michoacán, SEDESOH, in its cross-cutting area and contributing to educational goals.

- The Secretary of Health, SSA, in its federal and state cross-sectional area and contributing to the goals of improving the HDI index.

- $\quad$ The Congress of the Union, in its scope of the Chamber of Deputies, approval and budgetary regulation of the Superior Audit of the Federation.

- The Ministry of Finance and Public Credit, SHCP, in its federal and state scope, for design, programming and budget.

- National Council for the Evaluation of Social Development Policy, CONEVAL, in its national autonomous field of contribution in the design, planning and evaluation of social programs.

\section{General objectives}

Close the learning gap between CONAFE students and regular SEP students, in basic education in the state of Michoacán, based on the integral feeding of students, income and socioeconomic educational destiny of families in inequality, as well as the attention to the professional professional preparation, motor of development of the knowledge and knowledge of its students.

\section{Specific objectives}

1. Reduce the learning gap between CONAFE students and regular SEP students in the state of Michoacán, in the language and communication training field, in primary education in the state of Michoacán.

2. Guarantee teachers or Leaders for Community Education (LECs), professionalized, with a minimum level of higher education, undergraduate.

3. Certify the teacher training and professionalization of the current LECs that do not have an adequate or lower profile at the higher level, undergraduate. 
4. Have adequate and functional infrastructure for the educational attention of CONAFE students, with multipurpose classrooms and complete equipment.

5. Provide scholarships for academic and social achievement to CONAFE students that allow to enhance their skills, abilities, abilities and skills, as well as their full dedication to knowledge and knowledge.

\section{Strategic axes}

Income: Hiring, professionalization and teacher training policies are promoted, which directly index the school potential, and guarantee better incomes, a better professional profile and competitiveness that allows to guarantee a better standard of living of the educational actors involved. Social support economic policies are developed for students that guarantee their school permanence and a better socio-educational profile of CONAFE students.

Learning: With the objective of achieving better results and levels of learning of the implicit educational communities, the plans and programs of primary education are aligned to the national and international goals through the guarantee of incorporation of professionalized teaching staff in educational matters and with suitable profile. Participation in terms of equity of students to achieve better performance and learning will be a constant engine of the program and its actors in the implemented public policy.

Food and health: With the intention of strengthening the adequate feeding of the students, we will seek to contribute to the integration of school canteens, provided by the transverse programs of SEDESOL and SEDESOH, as well as the monitoring of health outcomes in the educational communities by the SSA.
Social Development: Considering that at a higher level of education in the communities there are better conditions of innovation, entrepreneurship, knowledge, knowledge and skills as an engine of economic and social development of the regions and productive sectors, the schoolcommunity relationship with crosscutting programs of SEDESOL and SEDESOH that allow the development of culture, sports and employment for the integral achievement of coexistence and social peace.

\section{Target population}

The actions will seek to attend the educational communities of CONAFE of primary education in Michoacán, an approximate universe of 72 thousand inhabitants that are developed in the communities, 485 LEC teachers, and 18 thousand students (CONAFE, 2016c; INEGI, 2017).

\section{Regulatory framework}

PND in its goal III. Mexico with quality education, Planning Law, PSE, PSS, PSDS, Art. 3rd, and 73, 26 and 134 Constitutional, General Education Law, Fiscal Coordination Law, General Law of the Professional Teaching Service, General Guidelines for the Evaluation of Federal Federal Public Administration Programs, Budget and Public Finance Law (CEFP, 2016; CESOP, 2015; CONAFE, 2015, 2016, 2016a, 2016b, 2016c; CONEVAL, 2018; DOF, 2013, 2015; PND, 2007, 2013; PSE, 2013).

\section{Conclusions}

An intervention proposal was designed based on an analysis and logical framework methodology (MML) outlining a relevant educational public policy to reduce the learning gap of CONAFE students with respect to regular SEP students in Michoacán. It constitutes a basis for the design of a program that translates said public policy into government actions considering all the phases of a governmental institutional program, from the making of public policy, implementation, control and evaluation, until reaching transparency and accountability. 
The proposal generated implies the use of public resources. Therefore, the process must weigh the ethical and moral exercise of public policy, as well as its transparency and accountability based on the guidelines and standards applicable to each case.

The decision to focus on primary education was based on the average permanence of school years that our country reaches the first year of secondary education. It is necessary to address the reasons for such limited achievements in the educational levels in our country and in Michoacán. The visible disarticulation that exists between organizations that provide basic education, and between educational sub-levels of the same organizations is also important to attend, be they preschool, primary, secondary, upper middle, and higher.

The proposal of educational public policy, which is outlined in the research through the Logical Framework focuses on the solution of the problem identified to close the learning gap in four aspects:

1. Attend the training and hiring of qualified and certified teachers in primary education as a means to strengthen the deficiencies in the teaching-learning process. Which obviously has a considerable economic cost; but its benefit would be equally significant to counteract the current negative effects.

2. Consider the importance of addressing a transcendental problem in our country: illiteracy and school lag, which will not be possible to eliminate, if we forget that in the most remote communities and where the absence of the educational service is practically null, it is one of the factors of This social delay. The nonattention of the subject has been a criticism by external and internal, national and international organizations, and that in Michoacán it does not allow to raise white flags, only discursively. The reality is different.
3. Another aspect that meets the proposal is: infrastructure and equipment, as well as lack of furniture and materials to work and develop the teaching-learning processes. The provision of additional budgetary resources to improve the current infrastructure, involves carrying or establishing 485 classrooms, one per community served, which in a comparative macro of infrastructure investment in the country does not really represent a significant budgetary impact, as is the motivational consequence of the educational communities involved to enable and achieve better standards of living and development in their communities and in their social and cultural environment.

4. Finally, the social and economic aspect that considers addressing the proposal by proposing direct scholarships to students based on their immediate educational and socio-cultural achievements, represents a very profitable investment. It should be recognized that the crosscutting social support or programs that other sectors of the government allocate to educational strengthening have not had the desired impact and results.

The information obtained from the field investigation makes it possible to determine that the incentives destined to the parents or guardians of the students end up being redirected to other needs and leave aside the fundamental reason for these supports for the strengthening of their children's learning. Therefore, the immediate recognition of the achievements that students have can represent a substantive incentive and a change of behavior in the perspective and results of education in the implicit educational communities.

For all the above, the proposal presented can be considered pertinent to solve the problem detected and establish an objective route of continuous improvement in primary education in Michoacán. 


\section{References}

CEFP (2016). Presupuesto de Egresos de la Federación 2016: Recursos Identificados para el Estado de Michoacán. Cámara de Diputados. LXIII Legislatura. México.

CESOP (2015). Evaluación del gasto educativo en México. Centro de Estudios Sociales y de Opinión Pública. Cámara de Diputados. LXIII legislatura. México.

CONAFE (2015). Programa Institucional del Consejo Nacional de Fomento Educativo: Logros 2014. CONAFE. México.

CONAFE (2016). Diagnóstico General Consejo Nacional de Fomento Educativo, 2016 Dirección de Planeación. SEP. México.

CONAFE (2016a). CONAFE en cifras. Educación comunitaria. Sistema Integral de Información e Infraestructura para el Fomento Educativo. Siiinafe. SEP. México.

CONAFE (2016b). Histórico. SEP. México.

CONAFE (2016c). Monitoreo CONAFE. Dirección de Comunicación y Cultura. SEP. México.

CONEVAL (2018). Sistema de Monitoreo de Programas Sociales. Lo que se mide se puede mejorar. Secretaria de Educación Pública 2017. México. Consultado en el 23 de enero de 2018. Enlace electrónico: http://sistemas.coneval.org.mx/SIMEPS/Progra mas

DOF (2013). Ley General del Servicio Profesional Docente. Cámara de Diputados. México.

DOF (2014a). Acuerdo No. 717 por el que se emiten los lineamientos para formular los Programas de Gestión Escolar. Del fortalecimiento de la autonomía de gestión escolar de las escuelas de educación básica. Capítulo II. SEP. México.

DOF (2014b). Programa institucional del Consejo Nacional de Fomento Educativo 20142018. Segunda Sección. Gobierno. México.
DOF (2015). Presupuesto de egresos de la federación para el ejercicio fiscal 2016. SEGOB. México.

Gobierno del Estado de Michoacán (2016). Programa anual de evaluación al Fondo de Aportaciones para la Nómina Educativa y el Gasto Educativo (FONE) 2016. SEE. Michoacán. México.

ILPES (2004). Metodología del Marco Lógico. CENEVAL. Santiago de Chile.

INEGI (2017). Censo de Escuelas, Maestros y Alumnos de Educación Básica y Especial (CEMABE). México. INEGI. www.uv.mx

OCDE (2016). Programa Internacional de Evaluación de los Alumnos (PISA). México. Enlace electrónico del portal: www.oecd.org

OCDE (2016a). Programa para la Evaluación Internacional de Alumnos PISA 2015. Resultados. Base de datos PISA 2015. México. Portal: www.oecd.org

PLANEA (2016). Plan Nacional para la Evaluación de los Aprendizajes. Portal PLANEA. SEP. México. www.planea.sep.gob.mx

PND (2007). Decreto por el que se aprueba el Plan Nacional de Desarrollo 2007-2012. SHCP. Cuarta Sección. P. 70. México.

PND (2013). Plan Nacional de Desarrollo 20132018. Segob. DOF. México.

PSE (2013). Programa Sectorial de Educación 2013-2018. Segob. DOF. México. 